\title{
The empirical link between export entry mode diversity and export performance: a
}

\section{contingency- and institutional-based examination}

João S. Oliveira ${ }^{a}$ (corresponding author)

${ }^{a}$ School of Business and Economics, Loughborough University, Loughborough,

Leicestershire, LE11 3TU, United Kingdom

E-mail: J.Oliveira@lboro.ac.uk

Telephone number: +44 (0) 1509228279

\section{Nahid Yazdani ${ }^{\mathrm{a}}$}

${ }^{a}$ School of Business and Economics, Loughborough University, Loughborough, Leicestershire, LE11 3TU, United Kingdom

E-mail: N.Yazdani@lboro.ac.uk

John W. Cadogan ${ }^{\mathrm{a}, \mathrm{b}}$

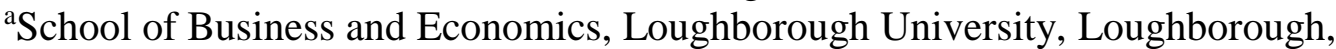

Leicestershire, LE11 3TU, United Kingdom

bLappeenranta University of Technology, Lappeenranta, Finland

Email: J.W.Cadogan@lboro.ac.uk

Ian R. Hodgkinson ${ }^{\mathrm{a}}$

${ }^{a}$ School of Business and Economics, Loughborough University, Loughborough,

Leicestershire, LE11 3TU, United Kingdom

Email: $\underline{\text { I.R.Hodgkinson@ @lboro.ac.uk }}$

Eleni Tsougkou ${ }^{\mathrm{a}}$

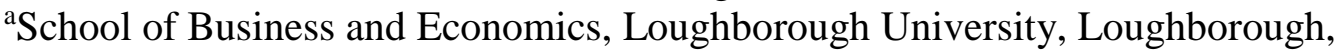

Leicestershire, LE11 3TU, United Kingdom

Email: E.Tsougkou@lboro.ac.uk

Ruey-Jer "Bryan" Jean"

Department of International Business, National Chengchi University, Taiwan

Email: bryan@nccu.edu.tw

Vicky M. Story ${ }^{\mathrm{a}}$

School of Business and Economics, Loughborough University, Loughborough,

Leicestershire, LE11 3TU, United Kingdom

Email: V.M.Story@1boro.ac.uk

Nathaniel Boso ${ }^{\mathrm{d}, \mathrm{e}, \mathrm{f}}$

${ }^{\mathrm{d}}$ KNUST School of Business, Kwame Nkrumah University of Science and Technology, Accra Road, Kumasi, Ghana

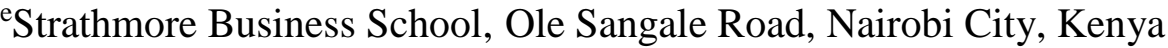

${ }^{\mathrm{f}}$ The University of Sydney Business School, H70, Abercrombie St \& Codrington St,

Darlington NSW 2006, Australia

Email: nboso@knust.edu.gh 


\section{Introduction}

Exporting is a critical mechanism for firms to expand internationally (Chen, Sousa, \& He, 2016). Firms can adopt various entry modes in their export activities, such as exporting via foreign sales agents, exporting through foreign importers and distributors, exporting through firms' foreign offices and subsidiaries, and exporting via collaborating with other firms (e.g. commercial franchising, licensing). The literature highlights entry mode(s) adopted by firms in exporting as crucial in predicting export performance (Cavusgil \& Zou 1994; Ngo, Janssen, Leonidou \& Christodoulides 2016). Existing studies often explore the performance outcomes of choosing one entry mode over another. In this context, there is a lack of knowledge regarding the impact of adopting multiple export entry modes on export performance. In other words, researchers have failed to examine the relationship between export entry mode diversity and export performance. This is unfortunate, as firms frequently adopt more than one entry mode across their portfolio of export markets (McNaughton, 2002). Therefore, a crucial question persists as to whether firms should pursue various entry modes in their export activities (i.e. increase their export entry diversity levels) or whether, alternatively, firms ought to adopt a single entry mode across their portfolio of export operations.

In the present study, we seek to address this important research gap by examining, for the first time, the impact of export entry mode diversity on export performance. Furthermore, we draw on contingency and institutional theories to identify potential moderators of such a link. Those are the magnitude of export institutional barriers faced by firms, the level of uncertainty that characterizes firms' export environments, and firms' degree of export geographical scope. We contend that export entry mode diversity has a positive effect on export performance. In addition, we argue that such an impact becomes greater when higher levels of institutional barriers characterize firms' export environments, and when firms face greater levels of environmental uncertainty in their export activities. Finally, we predict that entry 
mode diversity is more beneficial for export performance when firms pursue greater levels of export geographical scope. We test our theoretical model using cross-sectional survey data from 250 Chinese exporters.

Next, we present the theoretical background of our study and develop the model hypotheses. We then outline the methodology used and present our findings. We subsequently discuss the theoretical and managerial implications of our research. This is followed by a discussion of the study limitations and directions for future research. Finally, we present the main conclusions of the study.

\section{Theoretical background and hypotheses}

A critical decision that exporters face when entering foreign markets concerns the degree to which they take on sales and distribution responsibilities directly and, relatedly, the extent to which they interact with export market customers (e.g. Anderson \& Coughlan, 1987). Firms have a choice of possible entry modes, such as exporting via foreign sales agents, exporting through foreign importers and distributors, exporting through the firms' foreign offices and subsidiaries, and exporting via collaborating with other firms (e.g. commercial franchising, licensing). With very few exceptions (e.g. McNaughton, 2002), the bulk of existing research on export entry mode tends to focus on the pursuit of a particular type of export entry mode versus another (Li, He \& Sousa, 2017). Examples include direct versus indirect exporting (Hessels \& Terjesen, 2010; Ngo et al., 2016), exporting via a market channel versus via a cooperative channel (Arranz \& De Arroyabe, 2009), and exporting via integrated versus independent channel (Khemakhem, 2010). Yet, companies often use multiple entry modes over the same time period for the same product market, or across their different product markets (Hoppner \& Griffith, 2015). In this context, we put forward a more holistic view of export entry mode that considers a firm's entire portfolio of export activities. Specifically, we 
analyze the relationship between the extent to which firms adopt various export entry modes across their export activities, i.e. export entry mode diversity, and export performance. We also investigate critical contingencies of such a relationship, namely the level of export institutional barriers faced by firms, the degree of uncertainty of firms' export environments, and the level of export geographical scope carried-out by firms. Our conceptual model is depicted in Figure 1.

[Insert figure 1 about here]

\subsection{Entry mode diversity and export performance}

Adopting various entry modes across exporting operations (i.e. pursuing greater levels of export entry mode diversity) is a key contributor to enhanced export success, as it provides firms with greater knowledge about undertaking different types of operational arrangements (McNaughton, 2002). Firms can use the operational knowledge acquired in one market not only to boost performance in that market, but also to gain a competitive edge in other markets where they undertake similar operational arrangements. Greater export entry mode diversity also provides firms with greater levels of flexibility, making them more able to adapt their export strategies to meet diverse market conditions (Brouthers, Brouthers \& Werner, 2008). Such flexibility is a critical factor to attain superior performance in export markets, as firms typically export to multiple markets that differ in critical aspects, such as infrastructure, market size, market structure, or type of competition (e.g. Katsikeas, Samiee, \& Theodosiou, 2006). Additionally, diversifying export entry mode enables firms to spread the risks associated with any particular entry mode. Therefore, we put forward the following hypothesis:

H1: The greater the export entry mode diversity, the greater the firm's export performance. 


\subsection{Institutional barriers and investment uncertainty as moderators}

Entry into export markets is undertaken within the constraints of the institutional environments in these markets (Manolova \& Yan, 2008). Institutional barriers (e.g. political instability, corruption, crime, and theft) are the result of the behaviors of the institutions that characterize an economy, and have a critical role in shaping firms' competitive behaviors in that economy (Cahen, Lahiri, \& Borini, 2016). Institutional barriers are especially pertinent in the examination of export entry modes, as such barriers often present unusual constraints for the management of export operations (cf. Yaprak, 2012). Export entry mode diversity increases firms' flexibility levels, enabling them to successfully cope with diverse market conditions. Enhanced levels of flexibility will be especially important when firms need to deal with higher institutional barriers, as flexibility allows firms to adopt entry modes in foreign markets that are best suited to overcoming such institutional barriers (or, at least, reduce their negative impact on performance). Hence, it is likely that export entry mode diversity will become more beneficial for export performance as institutional barriers increase. Thus, we hypothesize that:

H2: Institutional barriers positively moderate the relationship between export entry mode diversity and the firm's export performance.

Investment uncertainty in foreign markets concerns the lack of assurance on the part of managers that investments in those markets will not be affected by the conditions that characterize them (e.g. political instability, economic volatility) (cf. Brouthers et al., 2008). Greater export entry mode diversity levels provide firms with enhanced levels of strategic flexibility and with greater knowledge in terms of undertaking different types of operational arrangements. Such factors will become particularly important when firms' export 
environments are more uncertain, since they will allow firms to successfully shift entry modes in foreign markets, if needed. Thus, export entry mode diversity is likely to be more beneficial for export performance when investment uncertainty is higher. Therefore, we hypothesize that:

H3: Investment uncertainty positively moderates the relationship between export entry mode diversity and the firm's export performance.

\subsection{Geographical scope as a moderator}

Export geographical scope relates to the number of export markets in which the firm operates. The flexibility and knowledge gains brought about by greater export entry mode diversity will become especially apparent in the case of firms that have greater levels of geographical scope. The underlying reasoning is that exporting to a higher number of markets is likely to present firms with greater levels of environmental diversity (e.g. infrastructure, market size) and, thus, with a higher need to adapt their export strategy, including the operational arrangements undertaken across export markets (Katsikeas et al., 2006). Accordingly, we anticipate that export entry mode diversity will be more useful for export performance when export geographical scope is greater. Therefore, we hypothesize that:

H4: Export geographical scope positively moderates the relationship between export entry mode diversity and the firm's export performance.

\section{Methodology}

\subsection{Sample and data collection}

We tested our model using survey data obtained from a directory of 22,000 exporters in the People's Republic of China (Zhou, Li, Sheng \& Shao, 2014). We randomly selected 
1000 firms in Beijing, Guangdong, Zhejiang, Shandong and Hebei, compiled by a business research firm. In line with established practice, we adopted the key informant approach (Sheng, Zhou, \& Li, 2011). We employed experienced interviewers to contact the key informants and conduct the interviews by telephone. We obtained 250 valid responses, representing a response rate of $25 \%$ (Chen et al., 2016). The firms in our sample operate in a wide variety of industries, including automotive, cosmetics, photography, food products, textiles, wood products, paper and allied products, printing, chemicals, metal fabrication, machines and equipment, and electronics. The average firm in our sample has 158 employees, exports to 17 countries, and accrues $58 \%$ of its sales revenues from exporting. Survey respondents occupy various positions within the firm, such as partner, marketing manager, sales manager, foreign trade manager, export business manager, export sales manager, and overseas sales manager.

\subsection{Measures}

This is the first study to investigate export entry mode diversity. Consequently, there is no available scale in the literature to measure it. Accordingly, we developed our own measure (see Appendix). Specifically, we developed a list containing six export entry modes. Such a list drew on established research (Anderson \& Coughlan, 1987; Klein \& Roth, 1990; Shervani, Frazier, \& Challagalla, 2007). Using a 100-point constant sum scale, we asked respondents to indicate the percentage of their firms' total export marketing operations performed via each of the six modes. We then calculated, for each firm, the standard deviation among the six scores provided. In an extreme case, where each of the six entry modes has the same weight in the firm's total export marketing operations, the standard deviation equals zero, indicating maximum export entry mode diversity. At the opposite extreme, i.e. in cases where one entry mode is responsible for $100 \%$ of the firm's total export marketing operations, the standard deviation equals 36.74. To assure that greater scores corresponded to higher levels of export 
entry mode diversity, we multiplied the standard deviations by -1 . We then adjusted the resulting scores to create our final export entry mode diversity scale, where 0 and 36.74 correspond, respectively, to the minimum and maximum export entry mode diversity. While our measure for export entry mode diversity is new, it follows the measurement approach undertaken in previous research, which analyses diversity regarding strategic choices (Krohmer, Homburg \& Workman, 2002).

We assessed export performance using a 3-item scale, adapted from Cadogan, Sundqvist, Puumalainen, and Salminen's (2005) export profit performance measure. Specifically, we asked respondents to evaluate their firms' export profit level, to indicate their satisfaction level with their firm's export profit, and to rate their firm's profit performance relative to predefined objectives. All items were measured using 5-point Likert type scales, and used the preceding year as reference point.

To measure institutional barriers, we developed a scale comprising 3 items. Precisely, we asked respondents to rate the extent to which, overall, institutional factors (e.g. court systems, political instability, widespread corruption, crime and theft) hindered their firms' export activities over the past 3 years. All items were measured using 7-point Likert scales. We assessed investment uncertainty using a single item, 7-point Likert type scale, based on existing studies (Brouthers \& Brouthers, 2003; Brouthers et al., 2008). Specifically, we asked managers to indicate the extent to which, in general, they felt uncertain about investing in their export markets over the preceding 3 years. We gauged export geographical scope of the firm's export operations by asking managers to indicate how many countries their firm exported to over the preceding year. Such a measure is an adaptation of Tallman and Li's (1996) 'country scope' scale. 
Regarding the control variables, we assessed firm size and export experience via logarithmic transformations of, respectively, the firm's number of employees and the number of years the firm had been exporting (Bijmolt \& Zwart, 1994; Wagner, 2001).

\section{Analyses}

\subsection{Measure Assessment}

To evaluate the validity and reliability of our measures we carried-out a confirmatory factor analysis (CFA). We used LISREL 8.80 (Jöreskog \& Sörbom, 2007). Table 1 shows measurement model statistics, and inter-construct correlations. As shown in Table 1, the chisquare of the measurement model is non-significant, suggesting an excellent fit with the data. All key fit indicators are within recommended thresholds and all average variances extracted (AVEs) and composite reliabilities surpass the 0.5 and 0.6 thresholds, respectively. Furthermore, all AVEs exceed the squares of the correlations between latent constructs, suggesting satisfactory discriminant validity of our measures. Therefore, our measures exhibit sufficient convergent and discriminant validity for model testing.

[Insert Table 1 about here]

\subsection{Model Specification}

We created single indicants to estimate interactions between latent constructs and utilized conventional product-term analysis to test for moderation effects (Ping, 1995). Our moderation hypotheses argue that the link between entry mode diversity and export performance is moderated by institutional barriers (H2), investment uncertainty (H3), and geographical scope (H4). Accordingly, we computed the corresponding multiplicative terms and entered them into the model equation. Following established procedure (e.g. Germann, 
Lilien, \& Rangaswamy, 2013) we also computed quadratic terms, both for the main effect of entry mode diversity and for the moderating effects. We included such terms in the model to control for non-linear effects. To reduce multicollinearity problems associated with the presence of interaction and quadratic terms, we adopted the procedure recommended by Little, Bovaird, and Widaman (2006) for orthogonalizing interaction and quadratic terms. We utilized the orthogonalized scores in the subsequent analysis. To guarantee model parsimony, we entered the direct effects of entry mode diversity, institutional barriers, investment uncertainty, and geographical scope as controls (Aiken \& West, 1991). We also included the direct effects corresponding to the control variables specified in the theoretical model, i.e. firm size and firm export experience.

To assess if our model makes a significant improvement regarding explaining variance in export performance relative to a more parsimonious explanation, we ran two models, namely Model 1 and Model 2. Model 1 includes only the main effects of export entry mode diversity, institutional barriers, investment uncertainty, geographical scope, firm size, and firm export experience. Model 2 is the full model and includes, in addition to the predictors of Model 1 , the interaction terms associated with moderating effects, as well as the quadratic terms. We estimated both models using Ordinary Least Squares (OLS) regression. Table 2 depicts the results attained.

[Insert Table 2 about here]

\section{Results}

Collinearity diagnostics indicate that multicollinearity is not a concern in this study (Hair et al., 2010). As depicted in Table 2, moving from Model 1 to Model 2 results in an increase of 9\% in R-square (from 5\% in Model 1 to 14\% in Model 2) and such an incremental 
increase in R-square (relative to Model 1$)$ is statistically significant $(p<.05)$. Since Model 1 is nested within Model 2 and Model 2 is superior to Model 1, we use Model 2 to test our hypotheses. Model 2 needs to be considered as a whole for drawing conclusions on $\mathrm{H} 1-\mathrm{H} 4$. For instance, it is not appropriate to look only at the coefficient associated with export entry mode diversity in Model 2 ( $\mathrm{B}=.09$; ns) and conclude that export entry mode diversity does not predict export performance. In this context, information on the link between export entry mode diversity and export performance is embedded in several interaction terms included in Model 2. Thus, evidence regarding all the interaction terms that include export entry mode diversity as an element needs to be combined to order to assess the effect of export entry mode diversity on export performance (c.f. Kam \& Franzese, 2007).

To offer hypotheses testing insights, we utilize a graphical approach to integrate the coefficients estimated in Model 2. Since the hypotheses of our model are directional, i.e. they predict positive or negative relationships with export performance, we use one-tailed tests to determine the statistical significance of the coefficients attained (Diamantopoulos \& Schlegelmilch, 1997). We combine such information with the unstandardized coefficients from Model 2 to plot graphical representations of the link between entry mode diversity and export performance (see Figure 2).

[Insert Figure 2 about here]

As illustrated in Figure 2, overall, entry mode diversity has a positive impact on export performance. Hence, H1 is supported. Furthermore, as depicted in Figure 2A, export entry mode diversity is more beneficial for export performance when institutional barriers are higher. Thus, $\mathrm{H} 2$ is also corroborated. Regarding H3, inspection of Figure $2 \mathrm{~B}$ reveals that the moderating effect of investment uncertainty on the export entry mode-export performance link 
is quite modest. Furthermore, the sign of the moderating effect varies across different levels of entry mode diversity. Under low-moderate levels of export entry mode diversity, the latter is less beneficial for export performance when investment uncertainty is greater. Conversely, under higher levels of export entry mode diversity, the latter is more beneficial for performance when investment uncertainty is higher. Finally, as shown in Figure 2C, export entry mode diversity becomes more useful for export performance when the firm has a greater level of geographical scope in their export operations. H4, is, therefore, supported.

\section{Discussion}

\subsection{Theoretical and Managerial Implications}

Export entry mode constitutes a critical decision for exporters, and firms often adopt multiple export entry modes. Yet, previous research has not examined whether, and to what extent, firms should adopt multiple export entry modes to increase export performance. In this study, we set out to address this important research gap by examining, for the first time, the relationship between export entry mode diversity and export performance, as well as critical contingencies of the relationship. We, therefore, make an important contribution to the international marketing literature. Our findings indicate that higher export entry mode diversity levels lead to enhanced firm-wide export success. Despite the coordination and resource allocation challenges involved in managing multiple export entry modes, greater entry mode diversity is beneficial for firms, as it allows them, for instance, to spread the risks associated with any one entry mode, and to be more flexible in adapting their export strategies to meet the environmental imperatives of different export markets (Brouthers et al., 2008).

Similarly to what happens with other strategic predictors of export performance (e.g. Navarro-García, Arenas-Gaitán, Rondán-Cataluña, \& Rey-Moreno, 2016), the usefulness of export entry mode diversity for export performance is affected by a number of contingencies. 
Institutional barriers present firms with obstacles with regard to the successful implementation of export strategies (Yaprak, 2012). Our results suggest that higher levels of export entry mode diversity are more beneficial for export performance when firms' export environments are characterized by higher institutional barriers. Export entry mode diversity seems to constitute, therefore, a useful tactic to handle the difficulties posed by export institutional barriers.

Findings also indicate that environmental uncertainty moderates the link between export entry mode diversity and export performance. Yet, such a moderating role is quite modest in strength and varies in signal depending on the degree of entry mode diversity itself: it lessens the positive impact of entry mode diversity on performance under low-moderate levels of diversity, and it strengthens it under higher levels of diversity. There may be, thus, other variables at play that affect the role of investment uncertainty as a moderator of the link between export entry mode diversity and export performance.

Results reveal that the positive effect of export entry mode diversity on export performance is boosted by the firm's degree of geographical scope. Hence, the benefits of entry mode diversity in terms of providing firms with enhanced flexibility to adapt strategies across markets become more visible when firms export to a greater number of markets. The reason is that exporting to a higher number of markets presents firms with greater environmental diversity (e.g. Katsikeas et al., 2006) and, thus, with an enhanced need to adapt export entry mode.

This study provides a number of managerial guidelines. Export entry mode diversity is an important predictor of export performance. It is, therefore, advisable that managers utilize greater entry mode diversity across their firms' portfolio of export activities. Managers also need to recognize that entry mode diversity enhances export performance to a greater extent when firms operate in environments characterized by higher institutional barriers. We, thus, recommend that managers evaluate their firms' export environments in terms of the levels of 
institutional barriers that characterize them, when deciding how much entry mode diversity to develop. Finally, the usefulness of entry mode diversity is leveraged by the geographical scope of firms' export activities. Thus, investments in greater entry mode diversification levels are especially recommended for firms that export to a greater number of markets.

\subsection{Limitations and Directions for Future Research}

Our study has several limitations, which we now discuss, in connection with future research directions. First, while the sample size attained was appropriate, a larger sample could have been useful to attain greater statistical power. Relatedly, the cross-sectional nature of this research limits the ability to infer causality based on the empirical results attained. Therefore, longitudinal studies using larger samples are desirable to corroborate the causality mechanisms put forward in the present study.

Additionally, our findings are based on data from one country, specifically, a developing nation. This limits our ability to generalize the findings attained to companies based in countries that have different institutional backgrounds. Hence, a potentially fruitful research direction consists of performing a comparative examination of the export entry mode-export performance link across firms from countries that are in different stages of economic development. Such research could shed light on country-level institutions that may help or hinder the role of entry mode diversity in leveraging export performance.

Furthermore, the literature does not provide a scale for export entry mode diversity. Thus, we developed our own measure, which is based on a list containing six entry modes. Such list draws on and is consistent with, established research (Klein \& Roth, 1990; Shervani et al., 2007). Yet, this list is not exhaustive, and it may be fruitful for researchers to incorporate additional entry mode types in future studies. Finally, we found that investment uncertainty plays a very modest moderating role on the entry mode diversity-export performance link, and 
that such a moderating effect varies in signal depending on the degree of export entry mode diversity pursued. Thus, it may be worthwhile for future research to examine whether there are variables not included in the present study that shape the strength and/or sign of the aforementioned moderating effect.

\section{Conclusions}

Enhancing export entry mode diversity is critical for increasing export performance. Managing export entry mode diversity is a complex task, which needs to account for a number of contingencies. Higher levels of export entry mode diversity are especially advantageous for firms that face higher institutional barriers in their export activities, and for firms that pursue greater levels of export geographical scope. Accordingly, it is recommended that decisions concerning export entry mode diversity take into account the levels of institutional barriers that characterize firms' export environments, as well as firms' export geographical scope. To the authors' best knowledge, this is the first study to examine the link between export entry mode diversity and export performance. This study constitutes, therefore, a platform on which future studies, on such an important topic, can be based. 


\section{References}

Aiken, L., \& West, S. G. (1991). Multiple regression: Testing and interpreting interactions. Thousand Oaks, CA: Sage Publications.

Anderson, E., \& Coughlan, A. T. (1987). International market entry and expansion via independent or integrated channels of distribution. Journal of Marketing, 51(1), 71-82.

Arranz, N., \& De Arroyabe, J. C. F. (2009). Internationalization process of Spanish small firms: Strategies, transactions and barriers. International Small Business Journal, 27(4), 420_ 441.

Bijmolt, T. H. A., \& Zwart, P. S. (1994). The impact of internal factors on the export success of Dutch small and medium-sized firms. Journal of Small Business Management, 32(2), 69-83.

Brouthers, K.D., \& Brouthers, L.E. (2003). Why service and manufacturing entry mode choices differ: The influence of transaction cost factors, risk and trust. Journal of Management Studies, 40(5), 1179-1204.

Brouthers, K. D., Brouthers, L. E., \& Werner, S. (2008). Real options, international entry mode choice and performance. Journal of Management Studies, 45(5), 936-960.

Cahen, F.R., Lahiri, S., \& Borini, F.M. (2016). Managerial perceptions of barriers to internationalization: An examination of Brazil's new technology-based firms. Journal of Business Research, 69(6), 1973-1979.

Cadogan, J. W., Sundqvist, S., Puumalainen, K., \& Salminen, R. T. (2005). Export marketing, inter-functional interactions, and performance consequences. Journal of the Academy of Marketing Science, 33(4), 520-535.

Cavusgil, S.T., \& Zou, S. (1994). Marketing strategy-performance relationship: An investigation of the empirical link in export market ventures. Journal of Marketing, $58(1), 1-21$. 
Chen, J., Sousa, C. M. P., \& He, X. (2016). The determinants of export performance: A review of the literature 2006-2014. International Marketing Review, 33(5), 626-670.

Diamantopoulos, A., \& Schlegelmilch, B.B. (1997). Taking the fear out of data analysis. London: Dryden.

Germann, F., Lilien, G. L. \& Rangaswamy, A. (2013). Performance implications of deploying marketing analytics, International Journal of Research in Marketing, 30(2), 114-128.

Hair, J. F., Black, W. C., Babin, B. J., Anderson, R. E., \& Tatham, R. L. (2010). Multivariate data analysis (7th ed.). NJ: Pearson Prentice Hall.

Hessels, J., \& Terjesen, S., (2010). Resource dependency and institutional theory perspectives on direct and indirect export choices. Small Business Economics, 34(2), 203-220.

Hoppner, J. J., \& Griffith, D. A. (2015). Looking back to move forward: A review of the evolution of research in international marketing channels. Journal of Retailing, 91(4), 610-626.

Jöreskog, K. \& Sörbom, D. (2007). LISREL 8.80. Lincolnwood: Scientific Software International, Inc.

Kam, C. K., \& Franzese Jr., R. J. (2007). Modeling and interpreting interaction hypotheses in regression analysis. MI: The University of Michigan Press.

Katsikeas, C.S., Samiee, S. \& Theodosiou, M. (2006). Strategy fit and performance consequences of international marketing standardization. Strategic Management Journal, 27(9), 867-890.

Khemakhem, R. (2010). Explaining the entry mode choice among Tunisian exporting firms: Development and test of an integrated model. European Journal of Marketing, 44(1/2), 223-244. 
Klein, S., \& Roth, V.J. (1990). Determinants of export channel structure: The effects of experience and psychic distance reconsidered. International Marketing Review, 7(5), 27-38.

Krohmer, H., Homburg, C., \& Workman, J.P. (2002). Should marketing be cross-functional? Conceptual development and international empirical evidence. Journal of Business Research, 55(6), 451-465.

Li, M., He, X., \& Sousa, C. M. P. (2017). A review of the empirical research on export channel selection between 1979 and 2015, International Business Review, 26(2), 303-323.

Little, T.D., Bovaird, J.A., \& Widaman, K.F. (2006). On the merits of orthogonalizing powered and product terms: Implications for modeling interactions among latent variables. Structural Equation Modeling, 13(4), 497-519.

Manolova, T. S., \& Yan, A. (2002). Institutional Constraints and entrepreneurial responses in a transforming economy: The case of Bulgaria. International Small Business Journal, 20(2), 163-184.

McNaughton, R. B. (2002). The use of multiple export channels by small knowledge-intensive firms. International Marketing Review, 19(2), 190-203.

Navarro-García, A., Arenas-Gaitán, J., Rondán-Cataluña, F.J., \& Rey-Moreno, M. (2016). Global model of export performance: Moderator role of export department. Journal of Business Research, 69(5), 1880-1886.

Ngo, V. D., Janssen, F., Leonidou, L. \& Christodoulides, P. (2016). Domestic institutional attributes as drivers of export performance in an emerging and transition economy. Journal of Business Research, 69(8), 2911-2922.

Ping Jr, R. A. (1995). A parsimonious estimating technique for interaction and quadratic latent variables. Journal of Marketing Research, 32(2), 336-347. 
Sheng, S., Zhou, K. Z., \& Li, J. J. (2011). The effects of business and political ties on firm performance: Evidence from China. Journal of Marketing, 75(1), 1-15.

Shervani, T. A., Frazier, G. \& Challagalla, G. (2007). The moderating influence of firm market power on the transaction cost economics model: An empirical test in a forward channel integration context. Strategic Management Journal, 28(6), 635-652.

Tallman, S. \& Li, J. (1996). Effects of international diversity and product diversity on the performance of multinational firms. Academy of Management Journal, 39(1), 179-196.

Wagner, J. (2001). A note on the firm size-export relationship. Small Business Economics, 17(4), 229-237.

Yaprak, A. (2012). Market entry barriers in China: A commentary essay. Journal of Business Research, 65(8), 1216-1218.

Zhou, K. Z., Li, J. J., Sheng, S., \& Shao, A. T. (2014). The evolving role of managerial ties and firm capabilities in an emerging economy: evidence from China. Journal of the Academy of Marketing Science, 42(6), 581-595. 
Table 1. Measurement Model Fit Statistics, Correlation Matrix, and Measurement Scale Properties.

\begin{tabular}{|c|c|c|c|c|c|c|c|}
\hline & $\chi^{2}$ (d.f.) & $p$-value & RMSEA & CFI & NFI & NNFI & SRMR \\
\hline Measurement model & $24.33(28)$ & .66 & .00 & 1.00 & .97 & 1.01 & .02 \\
\hline Measures & 1 & 2 & 3 & 4 & 5 & 6 & 7 \\
\hline 1. Entry mode diversity & - & & & & & & \\
\hline 2. Export performance & .15 & - & & & & & \\
\hline 3. Institutional barriers & .01 & -.09 & - & & & & \\
\hline 4. Investment uncertainty & .02 & $-.21^{*}$ & .07 & - & & & \\
\hline 5. Geographical scope & .02 & .12 & $.19^{*}$ & -.02 & - & & \\
\hline 6. Size & $.21 *$ & -.01 & -.08 & -.04 & .12 & - & \\
\hline 7. Export experience & -.07 & .01 & .01 & -.08 & $.20 *$ & $.38 * *$ & - \\
\hline Mean & 16.01 & 3.07 & 4.01 & 3.84 & 17.31 & 158.92 & 7.17 \\
\hline Standard deviation & 11.36 & .71 & 1.12 & 1.36 & 17.34 & 344.12 & 3.58 \\
\hline Composite reliability & N.A. & .54 & .74 & N.A. & N.A. & N.A. & N.A. \\
\hline Average variance extracted & N.A. & .77 & .89 & N.A. & N.A. & N.A. & N.A. \\
\hline \multicolumn{8}{|c|}{$\begin{array}{l}\text { * Correlation is significant at the } 5 \% \text { level. } \\
\text { ** Correlation is significant at the } 1 \% \text { level. } \\
\text { N.A. = not applicable. Because these three measures are single-item, composite reliability and average variance extracted are not } \\
\text { meaningful. } \\
\text { Notes: } \chi^{2}=\text { normal theory weighted least squares chi-square; d.f. = degrees of freedom; RMSEA = root mean square error of } \\
\text { approximation; CFI = comparative fit index; NFI = normed fit index; NNFI = non-normed fit index; SRMR = standardized root mean } \\
\text { square residual. }\end{array}$} \\
\hline
\end{tabular}


Table 2. Path coefficients, t-statistics, and R-square of Model 1 and Model 2.

\begin{tabular}{|c|c|c|c|c|}
\hline & \multicolumn{2}{|c|}{ Model 1} & \multicolumn{2}{|c|}{ Model 2 (main) } \\
\hline & B (standardized) & t-value & B (standardized) & t-value \\
\hline \multicolumn{5}{|l|}{ Variable } \\
\hline Export entry mode diversity & .09 & 1.40 & .09 & 1.46 \\
\hline Institutional barriers & -.08 & -1.32 & -.07 & -1.13 \\
\hline Investment uncertainty & -.15 & -2.40 & -.15 & -2.37 \\
\hline Geographical scope & .09 & 1.47 & .09 & 1.43 \\
\hline Firm size & -.06 & -.92 & -.06 & -.91 \\
\hline Firm export experience & .07 & 1.03 & .09 & 1.39 \\
\hline Export entry mode diversity $\mathrm{x}$ institutional barriers & & & .04 & .58 \\
\hline Export entry mode diversity $\mathrm{x}$ investment uncertainty & & & .11 & 1.78 \\
\hline Export entry mode diversity x geographical scope & & & -.10 & -1.60 \\
\hline Export entry mode diversity-squared & & & -.01 & -.16 \\
\hline Export entry mode diversity-squared $\mathrm{x}$ institutional barriers & & & .20 & 3.25 \\
\hline Export entry mode diversity-squared $x$ investment uncertainty & & & .04 & .56 \\
\hline Export entry mode diversity-squared x geographical scope & & & .14 & 2.26 \\
\hline R-square & \multicolumn{2}{|c|}{.05} & \multicolumn{2}{|c|}{.14} \\
\hline Change in R-square & & & \multicolumn{2}{|c|}{$.09 *$} \\
\hline
\end{tabular}

Note: One-tailed tests were used; critical t-value $=1.65$.

* R-squared change significant at $5 \%$. 
Figure 1. Conceptual model and hypotheses.

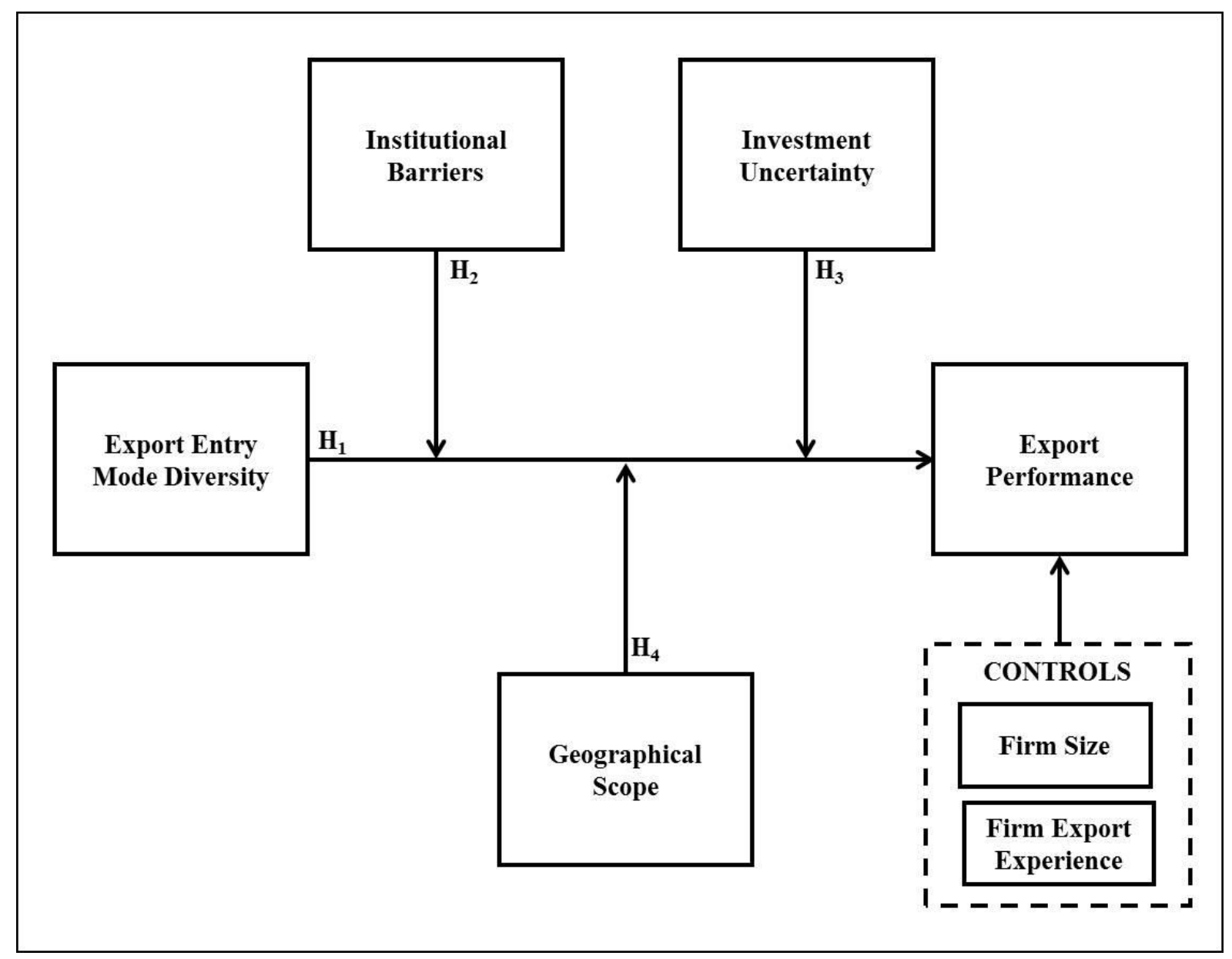


Figure 2. Export entry mode diversity-performance relationship under low and high values of moderating variables.

A. Export entry mode diversity-export performance link under low/high levels of institutional barriers

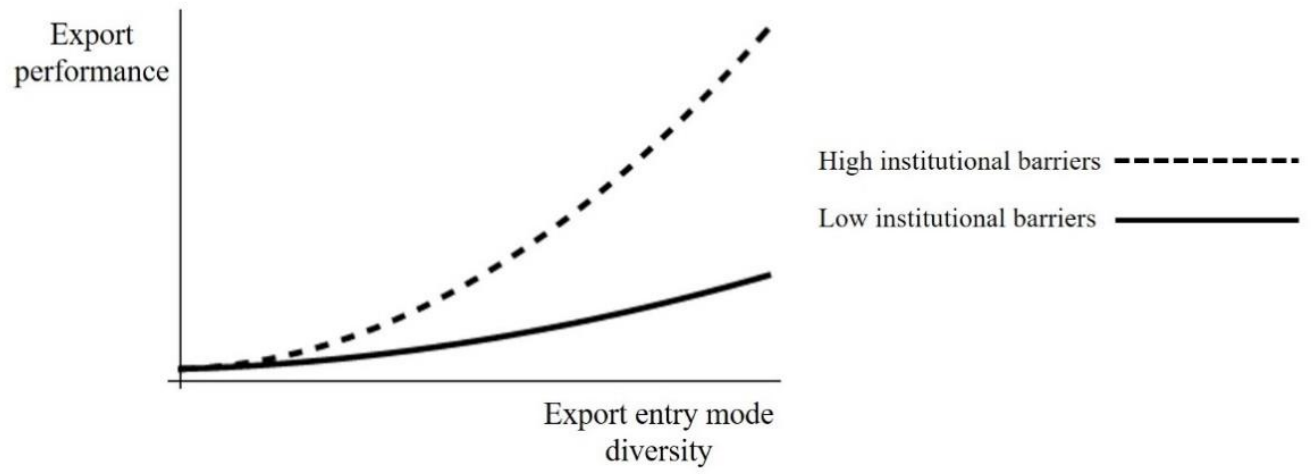

B. Export entry mode diversity-export performance link under low/high levels of investment uncertainty

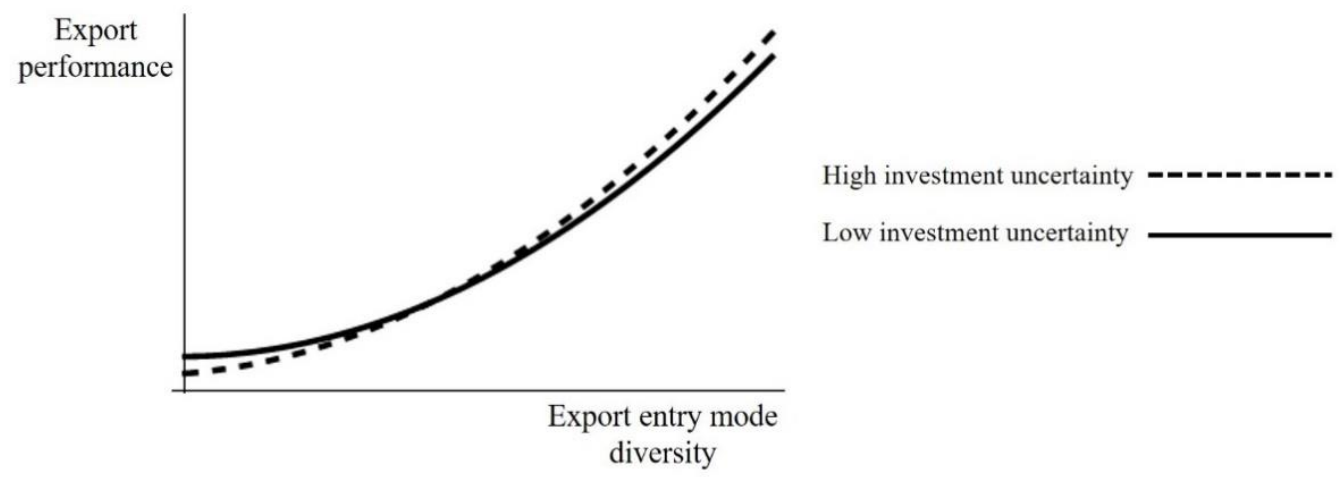

C. Export entry mode diversity-export performance link under low/high levels of geographical scope

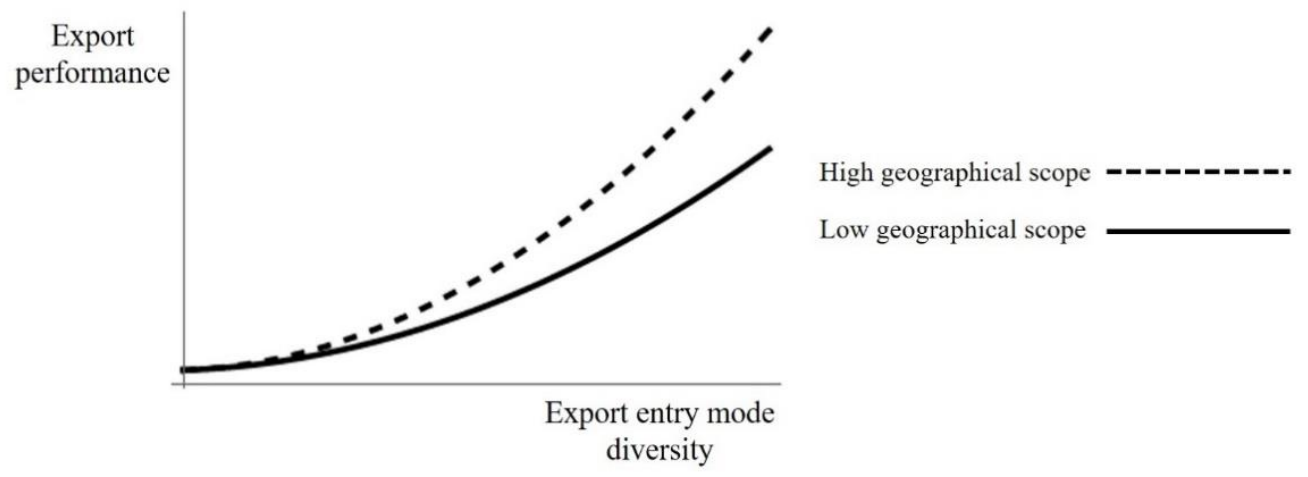




\section{Appendix - Measures used and their sources.}

Export entry mode diversity (based on Anderson \& Coughlan, 1989; Klein \& Roth 1990; Krohmer et al., 2002; Shervani et al., 2007)

Scale developed through first asking respondents, using a 100-point constant sum scale, to specify the percentage of their firms' total export marketing activities performed via each of the following export entry modes: (1) exporting via collaborations (e.g. joint ventures, piggy backing, commercial franchising, or licensing); (2) exporting through people operating from the domestic office (and not travelling overseas); (3) exporting via people operating from the firm's foreign offices and subsidiaries; (4) exporting via other company employees (salaried sales representatives) operating in the firm's foreign markets; (5) exporting via foreign sales agents, and; (6) exporting through foreign importers and distributors. The standard deviation among the scores attained was then calculated for each firm. In the extreme case, in which each of the six entry modes has the same weight in the firm's total export marketing activities, the standard deviation equals zero, indicating maximum export entry mode diversity. At the opposite extreme, i.e. in cases where one entry mode is responsible for $100 \%$ of the firm's total export marketing activities, the standard deviation equals 36.74. To guarantee that higher scores corresponded to greater levels of export entry mode diversity, the standard deviations were multiplied by -1 . The resulting scores were then adjusted to obtain our final export entry mode diversity measure, where 0 and 36.74, respectively, correspond to the minimum and maximum entry mode diversity.

Export Performance (adapted from Cadogan et al., 2005)

1. All things considered, we did well to achieve last year's export profit level. ( $1=$ "very strongly disagree"; 5 = "very strongly agree")

2. How satisfied are you with your export profit for last year? ( 1 = "strongly dissatisfied"; $5=$ "strongly satisfied")

3. In terms of our export profit objectives, last year's performance was... ( 1 = "far below expectations"; 5 = "far above expectations")

\section{Institutional barriers (new)}

Overall, across our export markets, institutional factors such as court systems, political

instability, widespread corruption, crime and theft, and other 'country' factors:

1. Made doing business in our export markets difficult. ( 1 = "very strongly disagree"; $7=$ "very strongly agree")

2. Acted as major barriers to doing business effectively in our export markets. ( $1=$ "very strongly disagree"; 7 = "very strongly agree")

3. Created hurdles for exporters operating in those markets. ( 1 = "very strongly disagree"; $7=$ "very strongly agree")

Investment uncertainty (based on Brouthers \& Brouthers, 2003; Brouthers et al., 2008)

We have felt uncertain when making decisions about whether to invest in our export ventures. ( 1 $=$ "not at all; 7 = to an extreme extent")

Geographical scope (adapted from Tallman \& $\mathrm{Li}$, 1996)

Over the past financial year approximately how many countries did your company export to?

Firm size (adapted from Bijmolt \& Zwart, 1994)

Approximately how many full-time staff does your company employ on the home-country wage book?

Firm export experience (adapted from Wagner, 2001)

Approximately how long has your company been exporting? 